Article

\title{
Boosting Political Trust with Direct Democracy? The Case of the Finnish Citizens' Initiative
}

\author{
Henrik Serup Christensen \\ Social Science Research Institute-Samforsk, Åbo Akademi University, 20500 Åbo, Finland; \\ E-Mail: henrik.christensen@abo.fi
}

Submitted: 7 November 2018 | Accepted: 4 February 2019 | Published: 27 June 2019

\begin{abstract}
Complementing representative democracy with direct-democratic instruments is perceived to boost levels of political trust. This was why Finland in 2012 introduced an agenda initiative, which gives citizens the right to propose legislation and thereby provides citizens a say between elections. However, it remains unclear whether involvement in such mechanisms helps restore political trust and what factors shape developments in political trust during involvement. This article contributes to this research agenda by examining how using the Finnish agenda initiative affected developments in political trust. The study uses two surveys to determine developments in political trust: a four-wave panel survey $(n=809-1419)$ and a cross-sectional survey $(n=481)$ where the perceived change method is used. The results suggest that using the citizens' initiative did not necessarily cause positive developments in political trust. Nevertheless, positive developments in political trust occurred when users achieved their intended aim and/or the process was seen as fair, which shows that direct-democratic instruments can increase levels of political trust under some circumstances.
\end{abstract}

\section{Keywords}

citizens' initiative; direct democracy; Finland; political trust

Issue

This article is part of the issue "The Politics, Promise and Peril of Direct Democracy", edited by Todd Donovan (Western Washington University, USA).

(C) 2019 by the author; licensee Cogitatio (Lisbon, Portugal). This article is licensed under a Creative Commons Attribution 4.0 International License (CC BY).

\section{Introduction}

Direct-democratic mechanisms give citizens the chance to take part in political decision-making (Altman, 2011; Qvortrup, 2013; Setälä \& Schiller, 2012). Despite their popularity, it remains unclear how involvement in these affects developments in political trust (Bauer \& Fatke, 2014; Kern, 2017), and critical voices maintain that such mechanisms frequently fail to improve democracy (Achen \& Bartels, 2016; Blaug, 2002; Dyck, 2009; Ladner \& Fiechter, 2012; Voigt \& Blume, 2015). Bauer and Fatke (2014) note that people involved in direct-democratic instruments may experience negative developments in political trust because of their involvement even when the availability has positive effects. To ascertain how being active shapes developments in political trust, it is imperative to use appropriate data and methods (Quintelier \& van Deth, 2014).
Furthermore, it remains unclear what factors shape developments in political trust, especially whether it is necessary to achieve the desired outcomes, or it suffices that decisions are taken in an appropriate manner (Christensen, Karjalainen, \& Nurminen, 2015; Esaiasson, Gilljam, \& Persson, 2012; Tyler, Casper, \& Fisher, 1989; Ulbig, 2008).

This study contributes to this research agenda by examining how supporting citizens' initiatives affected political trust in Finland, where a citizens' initiative was introduced in 2012. Citizens' initiatives allow citizens to put issues on the political agenda by collecting signatures in support of a proposal (Schiller \& Setälä, 2012, p. 1). A distinction is made between full-scale initiatives, where decisions are made through a ballot vote, and agenda initiatives, where representative bodies make the final decision (Schiller \& Setälä, 2012, p. 1). The Finnish citizens' initiative is an agenda initiative where the Finnish Parlia- 
ment takes the final decision on initiatives put forward by citizens. It is debated whether agenda initiatives are a type of direct democracy since they do not make citizens the final decision-makers (Altman, 2011; Qvortrup, 2013; Setälä \& Schiller, 2012), and some scholars refer to them as soft forms of direct democracy to avoid confusion (Jäske, 2017). Agenda initiatives resemble parliamentary e-petition systems (Lindner \& Riehm, 2011), where citizens also make proposals to parliament. However, since agenda initiatives lead to formal legislative proposals that are dealt with by parliamentary committees and requires a formal decision by parliament, they provide citizens with stronger agenda-setting powers than e-petition systems, where proposals can be dismissed without giving them serious consideration (Schiller \& Setälä, 2012, p. 6). Compared to referendums, which are rare in most political systems, agenda initiatives offer citizens a continuous say in political decision making, and the impact on legislation may even exceed that of ostensibly stronger mechanisms (Qvortrup, 2013, p. 71). Finally, such mechanisms may have particularly important repercussions for developments in political trust precisely because they rely on interaction with elected representatives (Carman, 2010). There are therefore valid reasons to assess the impact of agenda initiatives on political trust.

The hypotheses are examined with two surveys from users of two websites central for the functioning of the Finnish citizens' initiative, which allow for exploring developments in trust over time. The results show that users experienced negative developments in political trust, thereby casting doubts on the possibilities for boosting political trust through direct democracy. Nevertheless, the effects were positive when users achieved their goals, and/or the decision-making process was considered fair. Hence direct democratic involvement can have positive effects under certain circumstances.

\section{Direct-Democratic Involvement and Political Trust}

Direct democracy has been flourishing worldwide in recent decades (Altman, 2011; Qvortrup, 2013). However, the idea of sustaining democratic legitimacy by increasing popular involvement has been questioned. Achen and Bartels (2016, pp. 73-75) maintain that directdemocratic instruments fail to deliver policies favoured by a democratic majority, catering instead to the preferences of organized interests. Furthermore, even when majorities do prevail, it does not necessarily lead to better policies (Achen \& Bartels, 2016, p. 76). Such arguments and several empirical studies (Dyck, 2009; Ladner \& Fiechter, 2012; Voigt \& Blume, 2015) cast doubt on whether direct democracy can help restore positive attitudes towards the political system.

Political trust is here defined as 'a basic evaluative orientation toward the government founded on how well the government is operating according to people's normative expectations' (Hetherington, 1998, p. 791). Political trust has following Easton (1965) been considered a central element of political support (Dalton, 2004; Norris, 1999). According to Dalton (2004, pp. 23-25), political trust in institutions and actors serve as indicators for affective orientations that he considers equivalent to what Easton labels diffuse support. Although some argue that critical attitudes in the form of low political trust can be beneficial for democracy (Inglehart, 1997; Norris, 1999), many consider political trust necessary to achieve a stable democratic system (Easton, 1965; Hetherington, 1998; Marien \& Hooghe, 2011). Regardless of what level of trust is considered optimal for democracy, it is important to examine how political trust develops through directdemocratic involvement to understand how these participatory mechanisms affect the viability of democracy.

The link between direct democracy and political trust remains unclear as previous studies show conflicting results (Talpin, 2018, p. 409). It is a central idea of participatory democracy that political involvement fosters positive developments in civic attitudes and skills (Barber, 1984; Pateman, 1970). There are valid reasons to expect direct-democratic involvement to have a positive effect on trust since it provides citizens with a rare possibility to influence political decision-making, even when the act itself takes little effort. Empirically, Smith (2002) finds that inhabitants in US states with ballot initiatives have higher levels of political knowledge, while Gherghina (2016) finds that countries with more direct-democratic instruments have higher levels of regime support. Nevertheless, being politically active can also be a frustrating experience that does not necessarily appeal to ordinary citizens (Hibbing \& Theiss-Morse, 2002). Accordingly, Dyck (2009) and Voigt and Blume (2015) both find that direct-democratic involvement reduces levels of political trust and Ladner and Fiechter (2012) find that the impact of direct democracy at the local level in Switzerland is negligible.

These conflicting results show the importance of distinguishing between availability and usage of direct democracy. In their study of direct democracy in Switzerland, Bauer and Fatke (2014) find that the availability of direct democracy has positive consequences for political trust while usage has a negative association with political trust. Although intriguing, the authors do not explore the mechanism at the individual level and they rely on cross-sectional data and therefore cannot firmly establish causal linkages, as they also note. Most previous studies fail to determine developments in political trust over time. This highlights the importance of using appropriate methods and data when seeking to establish causal mechanisms for the link between political participation and attitudes, a point also made by Quintelier and van Deth (2014) in their study of how being politically active affects political attitudes.

Despite the conflicting results, the first hypothesis aligns with the positive view and states that:

H1. Using the citizens' initiative causes positive developments in political trust. 
However, involvement in itself may fail to generate positive developments in political trust (Ulbig, 2008). The ensuing hypotheses therefore concern what factors shape how involvement affects political trust. Here a current debate involves the role of outcome versus process satisfaction, where there is mixed empirical evidence on the relative importance of these two factors (Arnesen, 2017; Christensen et al., 2015; Esaiasson et al., 2012; Marien \& Kern, 2017; Tyler et al., 1989).

Previous studies show that there are consistent differences in developments in trust depending on whether participants achieve their goals, since several studies find a gap in satisfaction between electoral winners and losers (Anderson, Blais, Bowler, Donovan, \& Listhaug, 2005; Curini, Jou, \& Memoli, 2012) and policy satisfaction to generate positive political attitudes (Easton, 1965; Page, 1994). Budge (2012) considers it one of the primary benefits of direct-democratic instruments such as citizens' initiatives that they help ensure policy outcomes that are in line with the preferences of the median citizen. Marien and Kern (2017) also find that referendum voters are more likely to experience positive developments in political support when they get their preferred outcome. The notion that outcomes matters also entails that involvement through an agenda initiative, which is a soft form of direct democracy where citizens are not the final decision-makers, may cause negative developments in political trust. As Blaug (2002) points out, critical activists may well be disappointed with participatory institutions that fail to help them achieve their goals. This suggests that any positive developments in political trust only materialize when a citizens' initiative is approved. Based on this, the second hypothesis states that:

H2. Users who achieve their goal experience positive developments in political trust.

Other studies suggest that users may accept not getting their preferred outcomes as long as the results come about through a decision-making process that is perceived as fair (Carman, 2010; Christensen et al., 2015; Esaiasson et al., 2012; Tyler et al., 1989). According to this idea, users of the citizens' initiative may experience positive developments if they feel that their grievances are given due concern by decision-makers. Participants not only care about achieving certain policy goals, they also care about broader objectives such as ensuring a richer democratic dialogue that ensures that all decisions are reached through open discussions and careful attention to the pros and cons of the decisions. When they feel that this is the case, they are even willing to accept not getting their preferred outcome. The perception of procedural fairness may be even more important for mechanisms such as the agenda initiative, where the decision-making powers remain in the hands of parliament (Carman, 2010, p. 747). This also entails that participation can have detrimental effects for civic attitudes when participants feel that decision makers fail to take their demands seriously (Ulbig, 2008). This suggests that positive developments in political trust can occur when participants feel that the decision on an initiative was reached through a fair process. Based on this, the third and final hypothesis is:

H3. Users who are satisfied with the decision-making process experience positive developments in political trust.

The following section outlines how the hypotheses are examined.

\section{Data and Variables}

The Finnish citizens' initiative was introduced in 2012. According to the regulations, the organizers can submit an initiative to the Finnish Parliament if it gathers support from at least 50,000 Finnish citizens. The representatives must then decide whether to accept the citizens' initiative, possibly in an amended form, or reject it altogether. The official website www.kansalaisaloite.fi facilitates the collection of signatures in support of proposals by making it possible to collect signatures online. Prior to the launch of this, an independent website called Avoin Ministeriö (www.avoinminsterio.fi, English translation Open Ministry) aimed to crowdsource citizens' initiatives by allowing members to discuss the contents of individual initiatives and facilitate the collection of signatures (Christensen et al., 2015). Avoin Ministeriö was instrumental in developing contents and promoting four of the first initiatives where the Finnish parliament made decisions.

From the launch in 2012 until parliamentary elections in April 2015, citizens launched more than 300 initiatives that collected over one million signatures in support (Christensen, Jäske, Setälä, \& Laitinen, 2017). Nine of these managed to collect the required 50,000 supporters within the stipulated time limit and Parliament decided on six citizens' initiatives during 2012-2015. Parliament rejected all but one of the initiatives; an initiative to make marriage legislation gender neutral. Despite the limited legislative impact, the citizens' initiative is a popular mechanism that is widely believed to have improved Finnish democracy (Christensen et al., 2017, p. 421). However, as Bauer and Fatke (2014) argue, even when availability is beneficial, usage is not necessarily connected to positive developments in attitudes.

\subsection{Data}

The data come from two surveys administered to users of two different websites that facilitates the use of the citizens' initiative. The first survey consists of a four-wave panel data collected 2013-2015 among users on Avoin Ministeriö following decisions of Parliament on four initiatives. The first concerns the very first decision by Parliament on a citizens' initiative, which involved a pro- 
posal to ban fur farming (Ban Fur Farming). The second wave was conducted following the decision on an initiative on copyright legislation (Copyright), while the third wave measures attitudes following the decision on an initiative to make marriage legislation gender neutral (Gender neutral marriage legislation). This initiative gathered more than 150,000 supporters and was the first to be approved by Parliament. The fourth and final wave took place after a rejection of an initiative to make it voluntary to learn Swedish in Finnish elementary schools (Swedish). For the first wave, all users on Avoin Ministeriö received an invitation to fill in the survey by email, which 2147 respondents did. For the following three waves, invitations to fill in surveys were sent by email to these 2147 respondents following the decision of Parliament on the initiative in question. To ensure data quality, the dataset was subsequently restricted to respondents who adequately filled in at least two waves, meaning the number of included respondents in the first panel was restricted to 1419 respondents. The survey includes an overrepresentation of young males with a university education living in the Helsinki area. Attrition was present, but analysing the attrition pattern with respect to the demographic and attitudinal variables of interest (age, gender, education, political interest and social trust), ANOVA analyses show that the differences were only significant when it comes to age $(F(3$, $4174)=5.37, p<0.001)$ ), since respondents are older in the last wave (mean $40.6, \mathrm{SE}=0.48$ ) compared to the first (mean 38.5, SE $=0.34, \mathrm{p}<0.001$ ) and the second (mean 38.5, SE $=0.39, \mathrm{p}<0.01$ ) waves. Despite the decreasing number of respondents in the waves, it is not a uniform dropout of respondents. The response patterns show that about $1 / 3$ filled in all four rounds, another third filled in three rounds and the final third only filled in two rounds (round 1 and one more). Hence, even if a respondent did not fill in Wave 2, it is for example possible he or she did fill in Wave 3 and 4 . This panel data is used to test all three hypotheses.

The second survey is a cross-sectional survey of users on www.kansalaisaloite.fi collected during AprilMay 2016. The users were invited to fill in the survey by clicking a banner on the site and 481 respondents accepted to do so. This survey is valuable since it provides an alternative approach to discerning the impact of using the citizens' initiative over time. The survey includes measures that asks respondents to estimate the amount and direction of change in political trust they underwent because of their use of the citizens' initiative in line with the perceived change method (Hill \& Betz, 2005; Pratt, McGuigan, \& Katzev, 2000), which has been used in previous studies with similar aims (Åström, Jonsson, \& Karlsson, 2017). This survey is only used to test $\mathrm{H} 1$ on the consequences of involvement for developments in political trust. Even if it is less reliable than panel data for establishing developments over time, it makes it possible to determine whether participants also subjectively experience the developments objectively measured with panel data. Furthermore, this survey makes it possible to explore whether there are differences in the developments depending on the extent of involvement, i.e. how many initiatives the respondents supported.

An overview of the data is provided in the Appendix (data is available upon request to the author).

\subsection{Variables}

The dependent variable is political trust. The proper operationalization of this concept is disputed (Zmerli \& Hooghe, 2011), but I here follow the predominant approach in previous studies and conceive political trust as a one-dimensional phenomenon (Åström et al., 2017; Bauer \& Fatke, 2014; Dyck, 2009; Kern, 2017;). Exploratory factor analyses justify this approach since political trust is clearly one-dimensional in both surveys (see online Appendix). Furthermore, robustness checks show similar results for the individual trust items (see Appendix). Accordingly, political trust is measured with a sum index combining levels of trust in government, political parties, politicians, and the Parliament in all three surveys.

The main independent variable is direct-democratic involvement in the form of using the citizens' initiative. In the panel data from Avoin Ministeriö, the independent variable is whether the respondent supported a specific citizens' initiative in each round. The independent variable in the other survey also takes into consideration the extent of the involvement since the respondents indicate the approximate number of initiatives signed. These different operationalizations make it possible to draw firmer conclusions on the impact of using the citizens' initiative on political trust.

To examine the impact of process satisfaction on developments in political trust across rounds, a question is used that asks respondents whether they thought Parliament handled the initiative in a suitable manner. Respondents gave answers on a five-point scale 'Strongly agree'-'Strongly disagree' but these were recoded to a dichotomy whereby respondents who agree are satisfied while those who are neutral or disagree are unsatisfied. This coding entails a restrictive view of satisfaction, but excluding the neutral category leads to similar conclusions.

To ascertain the results, the models include control variables that have been argued to affect political trust: Age, gender, education, political interest and social trust (Dalton, 2004; Hetherington, 1998; Zmerli \& Hooghe, 2011). Similar control variables are used in both surveys, although the operationalizations differ slightly (see online Appendix).

\subsection{Methods of Analysis}

To examine $\mathrm{H} 2$ and $\mathrm{H} 3$ with panel data, a series of growth curve models analyse developments over time. Growth curve models are a special case of the random- 
effects model approach to analysing panel data where developments in longitudinal data are examined (Curran, Obeidat, \& Losardo, 2010; Singer \& Willett, 2003; RabeHesketh \& Skrondal, 2012). This multilevel approach models the shape of trajectories of individual subjects over time and how these trajectories vary randomly and systematically due to occasion level and subject-level covariates (Rabe-Hesketh \& Skrondal, 2012). Compared to traditional fixed effects models, this approach has several advantages (Curran et al., 2010). Most importantly for the present purposes, it is possible to include respondents even when they fail to answer every wave, although it is preferable to have several estimates over time for all respondents (Singer \& Willett, 2003, p. 148). A fixed effects model using the xtreg procedure in Stata showed similar substantial results.

For $\mathrm{H} 1$, a model examines the impact of using the citizens' initiative across rounds, while testing $\mathrm{H} 2$ and $\mathrm{H} 3$ involves including a three-way interaction effect to examine whether the effects of involvement and process satisfaction differ across rounds. These hypotheses are only examined in the panel data since this makes it possible to tie involvement to specific initiatives. Only the initiative proposing gender neutral marriage legislation was approved, meaning $\mathrm{H} 2$ suggests that the effect of supporting should be positive for this round and negative in the others whereas $\mathrm{H} 3$ predicts similar positive effects of process satisfaction in all rounds regardless of the outcome.

\section{Analysis}

Table 1 shows results for $\mathrm{H} 1$ on the developments in political trust because of involvement.

The significant estimates for signing initiatives in the Avoin Minsteriö survey $(B=-0.016, p<0.000)$ and the kansalaisaloite.fi survey $(B=-0.036, p<0.000)$ both suggest that using the citizens' initiative diminished political trust. Figure 1 shows the implications of signing for developments in trust.

Figure 1a shows that among Avoin Ministeriö users, using the citizens' initiative on average decreased political trust with about 0.016 on the scale $0-1$ when controlling for other factors. Although the effect is not particularly strong, the significant negative effect shows that there are no signs of the expected positive effect from involvement. The results from kansalaisaloite.fi in Figure $1 \mathrm{~b}$ show that the cumulative effect may be substantial, since the extent of involvement mattered for users on kansalaialoite.fi. Here political trust on average declined more drastically among more avid users. The results therefore clearly contradict $\mathrm{H} 1$ and the suggestion that involvement enhances political trust.

Hypotheses $\mathrm{H} 2$ and $\mathrm{H} 3$ concern how outcomes and process satisfaction affected developments in political trust. To test these propositions among Avoin Ministeriö users, the model in Table 2 includes a three-way interaction effect between involvement, process satisfaction

Table 1. Using the citizens' initiative and developments in political trust.

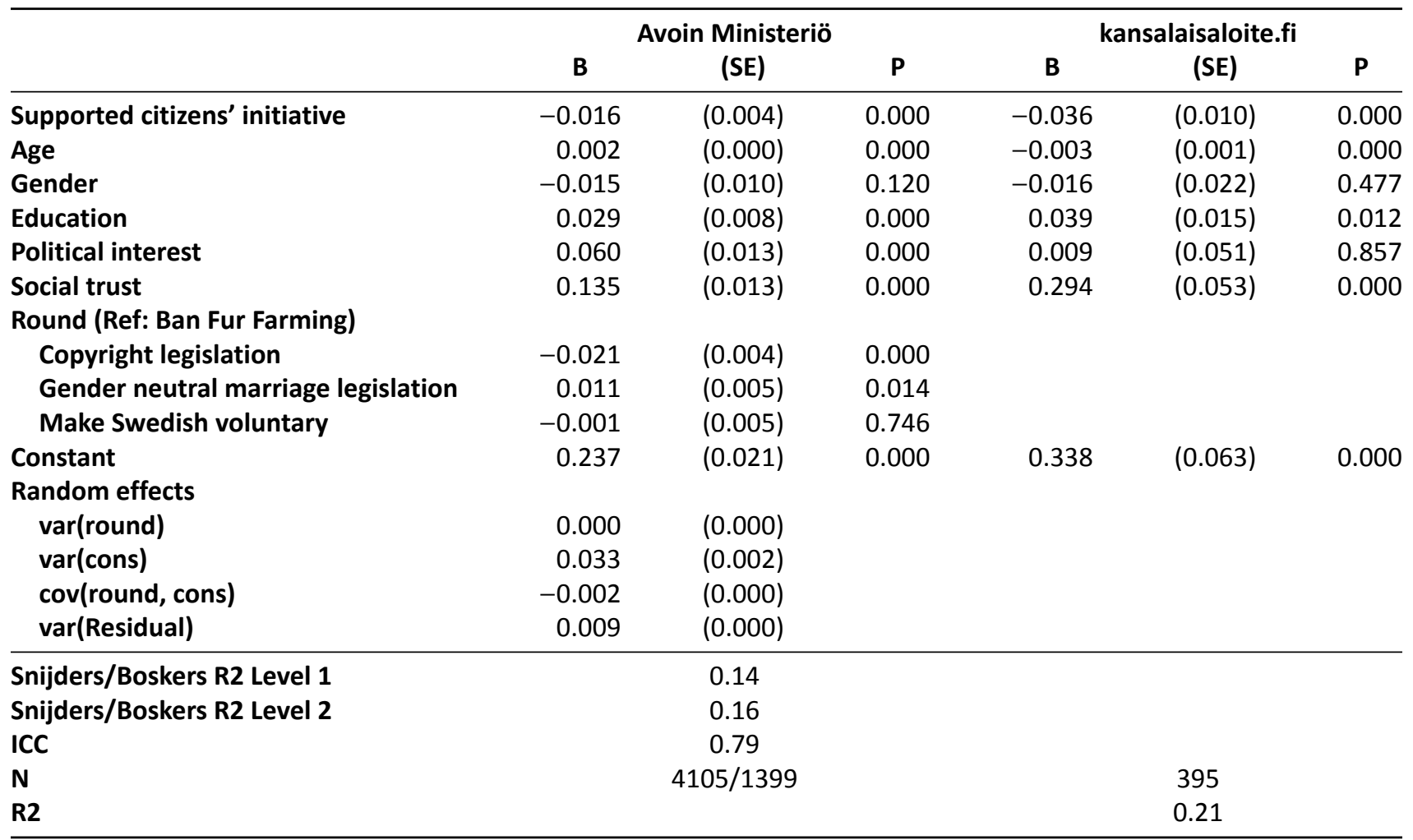

Notes: Avoin Ministeriö: Entries are coefficients (B) with robust standard errors (SE) and significance levels (P) from growth curve models estimated with the xtmixed command in Stata. Kansalaisaloite.fi: Entries are coefficients (B) from linear regression analyses with robust standard errors (SE) and significance levels (P). 
(a) Developments after supporting

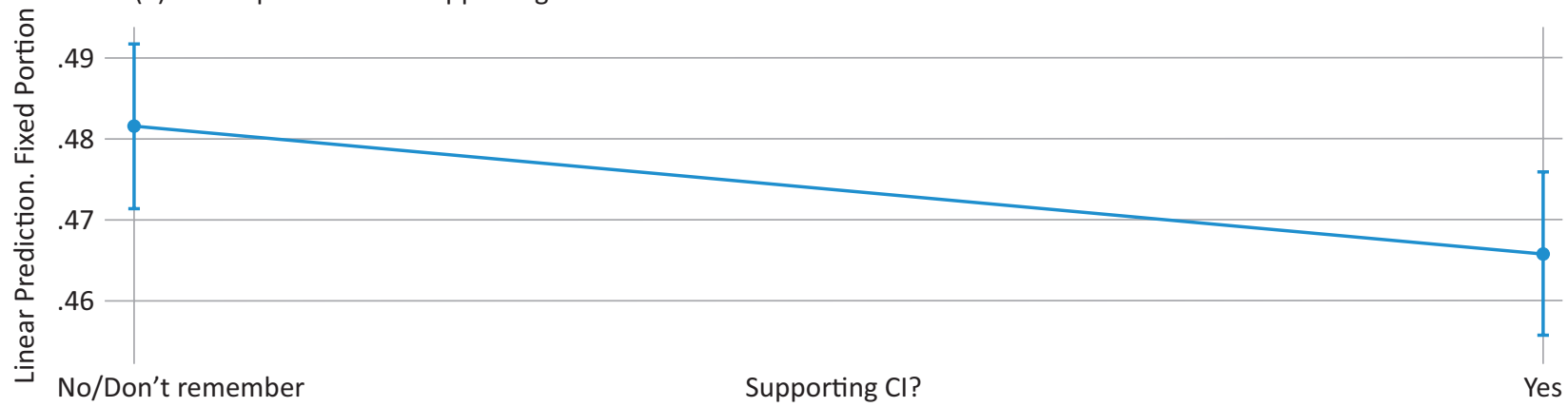

Source: Avoin Ministeriö

(b) Perceived developments in trust

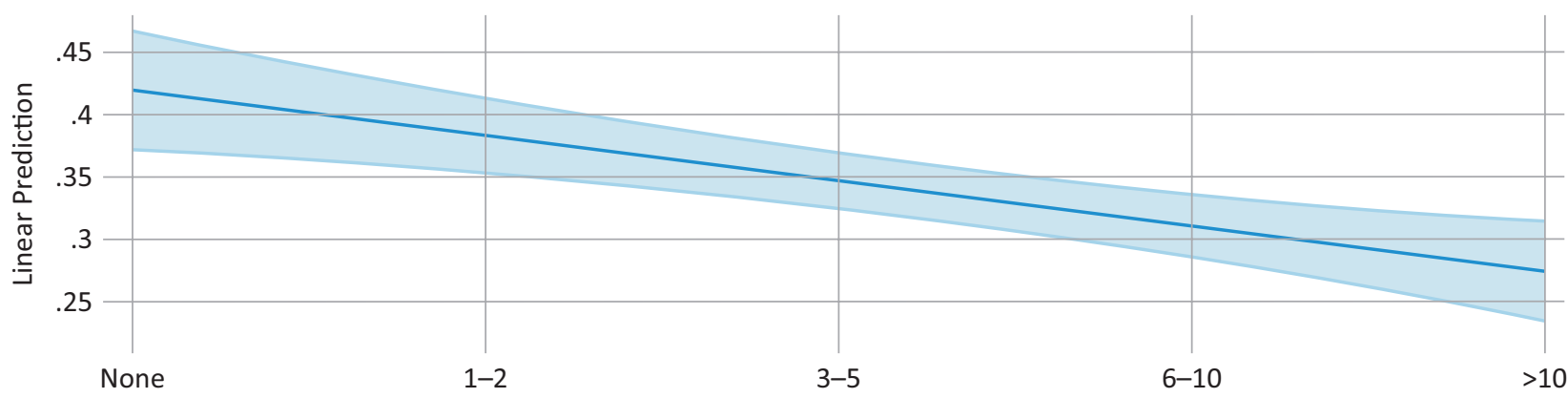

Extent of supporting

Source: Kansalaisaloite.fi

Figure 1. Effects on political trust from using the citizens' initiative: (a) Development after supporting, (b) Perceived development in trust.

and round to examine whether the effect of using the citizens' initiative differs across rounds. The expectation in line with $\mathrm{H} 2$ is here that the effect of supporting the initiative on gender-neutral marriage legislation should differ from the other three since this was the only initiative that Parliament approved, whereas $\mathrm{H} 3$ suggests that the effect of process satisfaction should be similar across rounds.

When it comes to the impact of outcomes, there is a significant interaction effect for the panel conducted following the decision on the gender-neutral marriage initiative, which means that the effect of using the citizens' initiative in this round differ from the reference category. There are no significant interaction effects when it comes to the impact of process satisfaction, although the estimate for the interaction effect concerning Equal marriage comes close $(B=0.030 ; p=0.054)$. It is noteworthy that the interaction effect between outcome support and process satisfaction is non-significant since this shows that the effect of process satisfaction is independent of whether the preferred outcome is achieved. To see what the results entail for the impact of outcome and process satisfaction, Figure 2 shows the differences in developments in trust for these two sets of interaction effects.

Figure 2a shows that there are clear differences in the predicted developments depending on the outcome of the citizens' initiative. When Parliament rejected the citizens' initiatives, the users developed lower levels of trust compared to those who did not make use of the citizens' initiative. For the initiative on gender-neutral marriage legislation, which Parliament approved, those who used the citizens' initiative developed a higher level of political trust compared to those who did not support this initiative. This pattern indicates that the outcome of the decision-making matters since using the citizens' initiative had a positive effect when Parliament approved the initiative. The pattern in Figure $2 b$ for process satisfaction differ strikingly since those who are satisfied with the process experience positive developments compared to the dissatisfied in all four rounds. These results support $\mathrm{H} 2$ and $\mathrm{H} 3$ since users experience positive developments in political trust when they either achieve the intended target or consider the process to be fair.

\section{Conclusions}

The results show that involvement served to further decrease levels of political trust among users on both Avoin Ministeriö and kansalaialoite.fi. Those who had signed an initiative on average experienced a decline in trust compared to those who did not sign. Although the decline in trust caused by signing a single initiative was small, the evidence from kansalaisloite.fi suggested that 
Table 2. Outcomes of citizens' initiatives and developments in political trust.

\begin{tabular}{|c|c|c|c|}
\hline & \multicolumn{3}{|c|}{ Avoin Ministeriö } \\
\hline & B & (SE) & $\mathbf{P}$ \\
\hline Supported citizens' initiative ( $\mathrm{Cl})$ & -0.019 & $(0.009)$ & 0.036 \\
\hline Process satisfaction & 0.044 & $(0.009)$ & 0.000 \\
\hline Age & 0.002 & $(0.000)$ & 0.000 \\
\hline Gender & -0.012 & $(0.009)$ & 0.211 \\
\hline Education & 0.028 & $(0.008)$ & 0.000 \\
\hline Political interest & 0.058 & $(0.013)$ & 0.000 \\
\hline Social trust & 0.135 & $(0.013)$ & 0.000 \\
\hline \multicolumn{4}{|l|}{ Round (Ref: Ban Fur Farming) } \\
\hline Copyright legislation & -0.018 & $(0.008)$ & 0.032 \\
\hline Gender neutral marriage legislation & -0.023 & $(0.011)$ & 0.028 \\
\hline Make Swedish voluntary & -0.003 & $(0.008)$ & 0.752 \\
\hline \multicolumn{4}{|c|}{ Supported $\mathrm{Cl}$ \# process satisfaction \# round (Ref: Ban Fur Farming) } \\
\hline Yes \# Yes \# Copyright legislation & 0.011 & $(0.025)$ & 0.646 \\
\hline Yes \# Yes \# Gender neutral marriage & -0.009 & $(0.021)$ & 0.681 \\
\hline Yes \# Yes \# Make Swedish voluntary & 0.030 & $(0.024)$ & 0.218 \\
\hline \multicolumn{4}{|l|}{ Supported $\mathrm{Cl}$ \# round (Ref Ban Fur Farming) } \\
\hline Yes \# Copyright legislation & 0.005 & $(0.012)$ & 0.710 \\
\hline Yes \# Gender neutral marriage & 0.041 & $(0.014)$ & 0.003 \\
\hline Yes \# Make Swedish voluntary & 0.001 & $(0.014)$ & 0.957 \\
\hline \multicolumn{4}{|l|}{ Process satisfaction \# round (Ref Ban Fur Farming) } \\
\hline Yes \# Copyright legislation & 0.012 & $(0.014)$ & 0.197 \\
\hline Yes \# Gender neutral marriage & 0.030 & $(0.016)$ & 0.054 \\
\hline Yes \# Make Swedish voluntary & 0.002 & $(0.012)$ & 0.855 \\
\hline Supported Cl (Yes) \# process satisfaction (Yes) & -0.022 & $(0.015)$ & 0.139 \\
\hline Constant & 0.235 & $(0.021)$ & 0.000 \\
\hline \multicolumn{4}{|l|}{ Random effects } \\
\hline var(round) & 0.000 & $(0.000)$ & \\
\hline var(cons) & 0.031 & $(0.002)$ & \\
\hline $\operatorname{cov}($ round, cons) & -0.002 & $(0.000)$ & \\
\hline var(Residual) & 0.009 & $(0.000)$ & \\
\hline Snijders/Boskers R2 Level 1 & & 0.18 & \\
\hline Snijders/Boskers R2 Level 2 & & 0.20 & \\
\hline ICC & & 0.79 & \\
\hline $\mathrm{N}$ & & 03/1399 & \\
\hline
\end{tabular}

Note: Entries are coefficients (B) with robust standard errors (SE) and significance levels (P) from growth curve models estimated with the xtmixed command in Stata.

the negative effect is cumulative, meaning that signing more initiatives leads to a more pronounced decrease in trust. There is therefore a risk that continuous use of the citizens' initiative creates a downward spiral of political trust.

This does not bode well for the prospects of restocking levels of trust with the help of citizens' initiatives. This may indicate that some users had unrealistic high expectations for the possibilities of determining legislative outcomes by using the citizens' initiative. The Finnish citizens' initiative does not make citizens the final decisionmakers but is a soft form of direct democracy that entails an interplay between direct and representative democracy (Jäske, 2017). While the introduction has empowered citizens, usage does not guarantee getting the preferred outcome as losing forms part of democratic de- cision making. This problem is clearly visible in the results for $\mathrm{H} 2$ and $\mathrm{H} 3$ concerning factors that shape developments in political trust.

For $\mathrm{H} 2$, outcomes clearly mattered for developments in trust since users experienced a positive development in political trust when Parliament approved the initiative. This finding corroborates previous studies showing a gap between winners and losers (Anderson et al., 2005; Curini et al., 2012; Marien \& Kern, 2017) and indicates that involvement is not enough, any positive impact hinges on citizens being empowered to achieve their desired target through their involvement (Budge, 2012; Ulbig, 2008). What also matters is how users perceive the quality of decision making (Carman, 2010; Christensen et al., 2015; Esaiasson et al., 2012; Tyler et al., 1989). Regardless of the outcome, users experienced positive de- 
(a) Supported\#Round

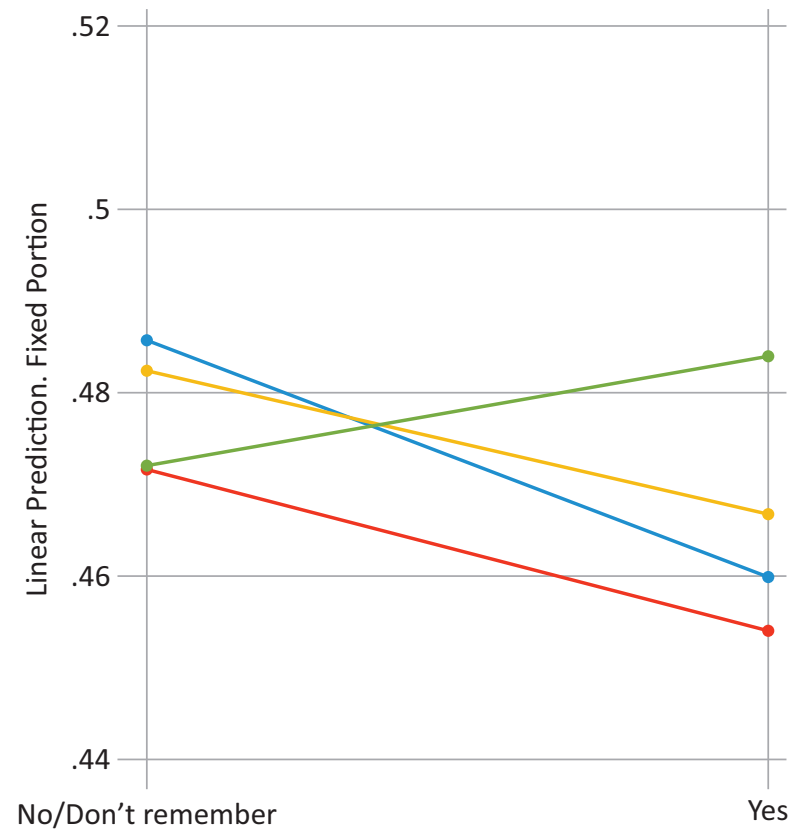

Supported initiative?

Source: Avoin Ministeriö (b) Satisfaction\#Round

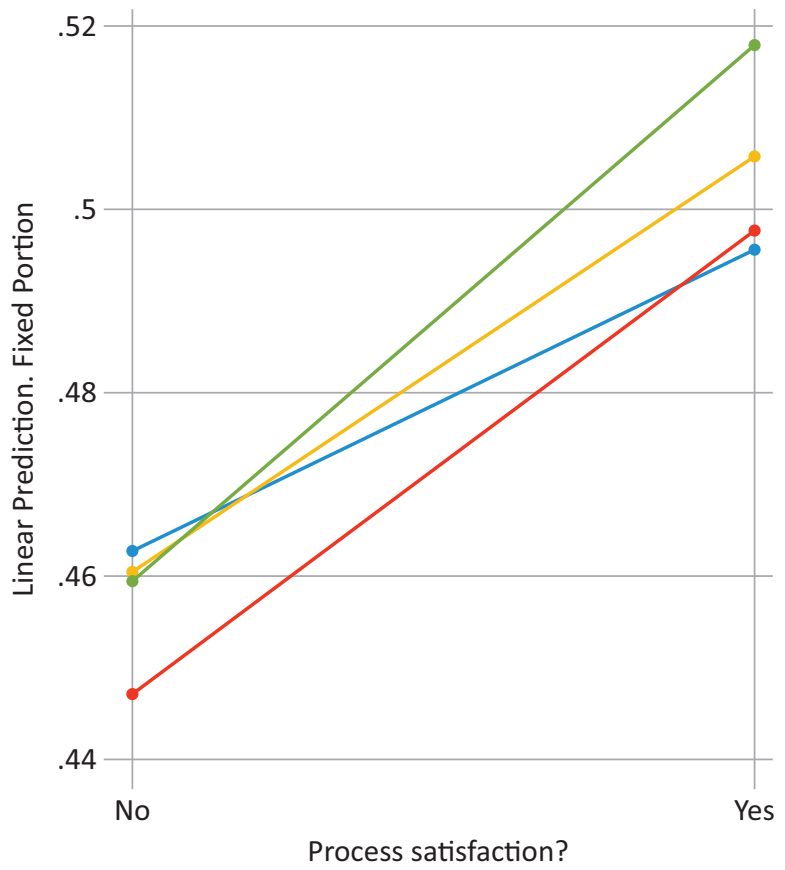

Source: Kansalaisaloite.fi

\section{Ban fur farming $\rightarrow$ Copyright}

Swedish

Figure 2. Differences in developments in political trust depending on outcome and process satisfaction: (a) Supported\#Round, (b) Satisfaction\#Round.

velopments in political trust when they felt that Parliament gave the proposal due consideration. This means that it is possible for decision-makers to generate positive developments not only by approving all initiatives, but also by giving them serious consideration and carefully explaining the motivations behind the decisions to the supporters. Hence it is possible to break any downward spiral either by giving people what they want, or at least convince them that their concerns are given adequate consideration (Carman, 2010).

These findings provide several theoretical insights. First, the results complement previous studies by establishing that involvement causes negative developments in political trust over time, thereby contradicting the expectation that direct-democratic involvement should generate positive political attitudes (Barber, 1984; Gherghina, 2016; Pateman, 1970). While the results are in line with other more negative findings (Dyck, 2009; Voigt \& Blume, 2015), they are also congruent with Bauer and Fatke (2014), who also find that the availability of direct democracy in Switzerland is connected to higher levels of political trust, whereas usage is connected to lower levels of trust. It is therefore important to distinguish between availability and use when discussing how direct democracy affects political trust. Furthermore, the relevant question may not be whether involvement causes negative or positive developments, but what factors shape these developments. The results also provide new insights into this question. As noted, outcomes and process satisfaction both matter and their effects were independent of each other. This entails that negative perceptions of the quality of decision making was not largely an artefact of not getting the desired outcome, as has been suggested (Arvai \& Froschauer, 2010). In the current study, the results suggest that participants were able to distinguish between outcomes and the quality of decision-making. It is an important task for future research to determine under what circumstances can decide whether a decision-making process is fair, regardless of whether they achieve their preferred outcome. Although speculative, it is worth keeping in mind that even a negative development in political trust is not necessarily bad for democracy since all forms of dissatisfaction are not equal (Christensen, 2016). When negative developments are accompanied by a simultaneous increase in the sense that involvement matters and hence increased mobilization, it may benefit democracy when critical citizens help hold decision-makers accountable (Åström et al., 2017).

These results come with uncertainties. The data used is not representative, and although findings on mechanisms may still be valid, it is unclear how pervasive it is in the general population. Furthermore, the data only covers a single approved initiative, meaning it remains unclear whether the results can be generalized beyond the specific issue of gender-neutral marriage legislation. This topic forms part of a postmodern or postmaterial political agenda (Inglehart, 1997). Based on the current re- 
sults, it is impossible to exclude the possibility that the results are only valid for measures of this type, especially considering that users tend to be younger citizens (Christensen et al., 2017) who are also more likely to support this agenda. The current analyses are also unable to take account of whether individuals supported government or opposition parties in the election, meaning their attitudes toward broader political developments are unclear. The results are also based on early experiences with an agenda initiative and different results may be found when the initiative becomes an ingrained part of the Finnish political system, or indeed in countries where citizens' initiatives traditionally form part of the political system. It should also be reiterated that agenda initiatives constitute a particular form of soft direct democracy, and these results may not be valid for other directdemocratic mechanisms. Regardless of these uncertainties, the findings indicate that although introducing citizens' initiatives can further political trust in the general population, a positive effect on users cannot be taken for granted.

\section{Acknowledgments}

This research was funded by Academy of Finland, Grant no. 285167: Democratic Innovations in Finland and Political Legitimacy.

\section{Conflicts of Interests}

The author declares no conflict of interests.

\section{References}

Achen, C. H., \& Bartels, L. M. (2016). Democracy for realists: Why elections do not produce responsive government. Princeton: Princeton University Press.

Altman, D. (2011). Direct democracy worldwide. Cambridge: Cambridge University Press.

Anderson, C. J., Blais, A., Bowler, S., Donovan, T., \& Listhaug, O. (2005). Losers' consent: Elections and democratic legitimacy. Oxford: Oxford University Press.

Arnesen, S. (2017). Legitimacy from decision-making influence and outcome favourability: Results from general population survey experiments. Political Studies, 65(1_suppl), 46-161.

Arvai, J. L., \& Froschauer, A. (2010). Good decisions, bad decisions: The interaction of process and outcome in evaluations of decision quality. Journal of Risk Research, 13(7), 845-859.

Åström, J., Jonsson, M. E., \& Karlsson, M. (2017). Democratic innovations: Reinforcing or changing perceptions of trust? International Journal of Public Administration, 40(7), 575-587.

Barber, B. R. (1984). Strong democracy: Participatory politics for a new age. Berkeley: University of California Press.
Bauer, P. C., \& Fatke, M. (2014). Direct democracy and political trust: Enhancing trust, initiating distrust-or both? Swiss Political Science Review, 20(1), 49-69.

Blaug, R. (2002). Engineering democracy. Political Studies, 50(1), 102-116.

Budge, I. (2012). Implementing popular preferences: Is direct democracy the answer? In K. Newton \& B. Geissel (Eds.), Evaluating democratic innovations: Curing the democratic malaise? (pp. 23-38). London and New York, NY: Routledge.

Carman, C. (2010). The process is the reality: Perceptions of procedural fairness and participatory democracy. Political Studies, 58(4), 731-751.

Christensen, H. S. (2016). All the same? Examining the link between three kinds of political dissatisfaction and protest. Comparative European Politics, 14(6), 781-801.

Christensen, H. S., Jäske, M., Setälä, M., \& Laitinen, E. (2017). The Finnish citizens' initiative: Towards inclusive agenda-setting? Scandinavian Political Studies, 40(4), 411-433.

Christensen, H. S., Karjalainen, M., \& Nurminen, L. (2015). Does crowdsourcing legislation increase political legitimacy? The case of Avoin Ministeriö in Finland. Policy and Internet, 7(1), 25-45.

Curini, L., Jou, W., \& Memoli, V. (2012). Satisfaction with democracy and the winner/loser debate: The role of policy preferences and past experience. British Journal of Political Science, 42(2), 241-261.

Curran, P. J., Obeidat, K., \& Losardo, D. (2010). Twelve frequently asked questions about growth curve modeling. Journal of Cognition and Development: Official Journal of the Cognitive Development Society, 11(2), 121-136.

Dalton, R. J. (2004). Democratic challenges, democratic choices: The erosion of political support in advanced industrial democracies. Oxford: Oxford University Press.

Dyck, J. J. (2009). Initiated distrust: Direct democracy and trust in government. American Politics Research, 37(4), 539-568.

Easton, D. (1965). A systems analysis of political life. New York, London and Sydney: John Wiley \& Sons.

Esaiasson, P., Gilljam, M., \& Persson, M. (2012). Which decision-making arrangements generate the strongest legitimacy beliefs? Evidence from a randomised field experiment. European Journal of Political Research, 51(6), 785-808.

Gherghina, S. (2016). Direct democracy and subjective regime legitimacy in Europe. Democratization, 24(4), 1-19.

Hetherington, M. J. (1998). The political relevance of political trust. American Political Science Review, 92(4), 791-808.

Hibbing, J. R., \& Theiss-Morse, E. (2002). Stealth democracy: Americans' beliefs about how government should work. Cambridge: Cambridge University Press. 
Hill, L. G., \& Betz, D. L. (2005). Revisiting the retrospective pretest. American Journal of Evaluation, 26(4), 501-517.

Inglehart, R. (1997). Modernization and postmodernization: Cultural, economic, and political change in 43 societies. Princeton: Princeton University Press.

Jäske, M. (2017). 'Soft' forms of direct democracy: Explaining the occurrence of referendum motions and advisory referendums in Finnish local government. Swiss Political Science Review, 23(1), 50-76.

Kern, A. (2017). The effect of direct democratic participation on citizens' political attitudes in Switzerland: The difference between availability and use. Politics and Governance, 5(2), 16-26.

Ladner, A., \& Fiechter, J. (2012). The influence of direct democracy on political interest, electoral turnout and other forms of citizens' participation in Swiss municipalities. Local Government Studies, 38(4), 437-459.

Lindner, R., \& Riehm, U. (2011). Broadening participation through e-petitions? An empirical study of petitions to the German parliament. Policy \& Internet, 3(1), 63-85.

Marien, S., \& Hooghe, M. (2011). Does political trust matter? An empirical investigation into the relation between political trust and support for law compliance. European Journal of Political Research, 50(2), 267-291.

Marien, S., \& Kern, A. (2017). The winner takes it all: Revisiting the effect of direct democracy on citizens' political support. Political Behavior, 40(4). https://doi. org/10.1007/s11109-017-9427-3

Norris, P. (Ed.). (1999). Critical citizens: Global support for democratic government. Oxford: Oxford University Press.

Page, B. I. (1994). Democratic responsiveness? Untangling the links between public opinion and policy. $P S$ Political Science and Politics, 27(1), 25-29.

Pateman, C. (1970). Participation and democratic theory. Cambridge: Cambridge University Press.

Pratt, C. C., McGuigan, W. M., \& Katzev, A. R. (2000). Measuring program outcomes: Using retrospective pretest methodology. American Journal of Evalua- tion, 21(3), 341-349.

Quintelier, E., \& van Deth, J. W. (2014). Supporting democracy: Political participation and political attitudes. Exploring causality using panel data. Political Studies, 62(1_suppl), 153-171.

Qvortrup, M. (2013). Direct democracy: A comparative study of the theory and practice of government by the people. Manchester: Manchester University Press.

Rabe-Hesketh, S., \& Skrondal, A. (2012). Multilevel and longitudinal modeling using Stata, Vol 1: Continuous responses. College Station, TX: Stata Press.

Schiller, T., \& Setälä, M. (2012). Introduction. In M. Setälä $\&$ T. Schiller (Eds.), Citizens' initiatives in Europe: Procedures and consequences of agenda-setting by citizens (pp. 1-14). London: Palgrave Macmillan UK.

Setälä, M., \& Schiller, T. (Eds). (2012). Citizens' initiatives in Europe: Procedures and consequences of agendasetting by citizens. London: Palgrave Macmillan.

Singer, J. D., \& Willett, J. B. (2003). Applied longitudinal data analysis: Modeling change and event occurrence. Oxford: Oxford University Press.

Smith, M. A. (2002). Ballot initiatives and the democratic citizen. The Journal of Politics, 64(3), 892-903.

Talpin, J. (2018). Do referendums make better citizens? The effects of direct democracy on political interest, civic competence and participation. In L. Morel \& M. Qvortrup (Eds.), The Routledge handbook to referendums and direct democracy (pp. 405-418). London: Routledge.

Tyler, T. R., Casper, J. D., \& Fisher, B. (1989). Maintaining allegiance toward political authorities: The role of prior attitudes and the use of fair procedures. American Journal of Political Science, 33(3), 629-652.

Ulbig, S. G. (2008). Voice is not enough. Public Opinion Quarterly, 72(3), 523-539.

Voigt, S., \& Blume, L. (2015). Does direct democracy make for better citizens? A cautionary warning based on cross-country evidence. Constitutional Political Economy, 26(4), 391-420.

Zmerli, S., \& Hooghe, M. (Eds). (2011). Political trust: Why context matters. Colchester: ECPR Press.

\section{About the Author}

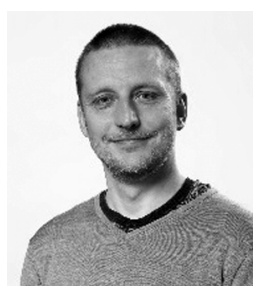

Henrik Serup Christensen (henrik.christensen@abo.fi) is Academy Research Fellow at the Social Science Research Institute-Samforsk at Åbo Akademi University in Turku, Finland. His current research project financed by the Academy of Finland (2015-2020) examines how democratic innovations has affected the political legitimacy in Finland. He has published on these and related topics in international journals such as Political Studies, International Journal of Public Opinion Research, Comparative European Studies, European Societies, Government \& Opposition and Acta Politica. 


\section{Appendix}

Table A1. Characteristics of surveys on www.avoinministerio.fi and www.kansalaisaloite.fi.

\begin{tabular}{|c|c|c|c|c|c|}
\hline & \multicolumn{4}{|c|}{ Avoin Ministeriö } & \multirow[t]{2}{*}{ Kansalaisaloite.fi } \\
\hline & Wave 1 & Wave 2 & Wave 3 & Wave 4 & \\
\hline Type & Panel & Panel & Panel & Panel & Cross-sectional \\
\hline Date of collection & June 2013 & October 2014 & December 2014 & March 2015 & April-May 2016 \\
\hline Topic & $\begin{array}{l}\text { Ban Fur } \\
\text { Farming }\end{array}$ & $\begin{array}{l}\text { Copyright } \\
\text { legislation }\end{array}$ & $\begin{array}{c}\text { Gender-equal } \\
\text { marriage legislation }\end{array}$ & $\begin{array}{l}\text { Voluntary } \\
\text { Swedish }\end{array}$ & $\begin{array}{c}\text { All initiatives launched } \\
\text { on website }\end{array}$ \\
\hline $\begin{array}{l}\text { Contact } \\
\text { method }\end{array}$ & $\begin{array}{l}\text { Email to all } \\
\text { participants } \\
\text { on website }\end{array}$ & $\begin{array}{c}\text { Email to those } \\
\text { who filled in } \\
\text { Wave } 1\end{array}$ & $\begin{array}{c}\text { Email to those } \\
\text { who filled in } \\
\text { Wave } 1\end{array}$ & $\begin{array}{c}\text { Email to those } \\
\text { who filled in } \\
\text { Wave } 1\end{array}$ & Banner \\
\hline Emails sent & About 10000 & 2147 & 2147 & 2147 & \\
\hline Filled in survey & 2147 & 1022 & 930 & 809 & 481 \\
\hline Valid $n$ & 1419 & 1022 & 930 & 809 & 481 \\
\hline
\end{tabular}

Table A2. Operationalisation of variables.

\begin{tabular}{|c|c|c|}
\hline & Survey Avoin Ministeriö & Survey Kansalaisaloite.fi \\
\hline \multicolumn{3}{|c|}{ Dependent variables } \\
\hline Political trust & $\begin{array}{l}\text { Sum index coded to vary between 0-1 based } \\
\text { on trust in government, political parties, } \\
\text { politicians, and the Parliament (each item } \\
\text { scored on 0-10 scale; Cronbach's alpha }=.92 \text { ). }\end{array}$ & $\begin{array}{l}\text { Development in political trust: Sum index } \\
\text { coded 0-1 based on perceived change in } \\
\text { trust in government, political parties, } \\
\text { politicians, and the Parliament (each item } \\
\text { scored on five point Likert scale: 'Increased a } \\
\text { lot'-'Decreased a lot'; Cronbach's alpha = .94). }\end{array}$ \\
\hline
\end{tabular}

\section{Independent variables and control variables}

Supported citizens' initiative

Dichotomous: Supported specific initiative in each round: Yes (1)/No or do not remember (0).

Process satisfaction

Age

Gender

Education

Political interest

Social trust
'Parliament handled the citizens' initiative in a suitable manner', Likert scale with 5 categories: 'Agree completely-Completely disagree': coded dichotomous Agree completely + Agree $=1$ / Neutral, Disagree and Disagree completely $=0$.

Age in years (2013-year of birth).

Dichotomy, Male $=1$.

Highest level of educational attainment, 4 categories. Coded to vary between 0-1 (Highest level of education attainment).

Level of political interest, 4-point scale 'Not interested at all'-'Very interested'. Coded to vary between 0-1 (High interest).

'Most people can be trusted or you can't be too careful', scale $0-10$, recoded to vary between $0-1$ (Highest level of social trust).
Extent of supporting: 'Did not support any ', 'Supported 1-2', 'Supported 3-5', 'Supported 6-10', 'Supported more than 10'. Coded to vary between 0-1.

N/A

Age in years (2016-year of birth).

Dichotomy, Female $=0$, Male $=1$.

Highest level of educational attainment, 4 categories. Coded to vary between 0-1 (Highest level of education attainment).

Level of political interest, 4-point scale 'Not interested at all'-'Very interested'. Coded to vary between 0-1 (High interest).

Perceived change in trust in other people because of involvement in citizens' initiative, answer on five-point Likert scale: 'Increased a lot'-'Decreased a lot'; coded to vary between 0-1 (Increased a lot). 
Table A3. Descriptive statistics of variables.

\begin{tabular}{|c|c|c|c|c|c|}
\hline Survey: Avoin Ministeriö & $\mathbf{n}$ & mean & SD & Min & Max \\
\hline \multicolumn{6}{|l|}{ TOTAL } \\
\hline Political trust & 4158 & 0.47 & 0.21 & 0.00 & 0.98 \\
\hline Supported citizens' initiative & 4180 & 0.48 & 0.50 & 0.00 & 1.00 \\
\hline Process satisfaction & 4177 & 0.32 & 0.47 & 0.00 & 1.00 \\
\hline Age & 4178 & 39.02 & 13.09 & 17 & 80 \\
\hline Gender ( $1=$ male $)$ & 4136 & 0.64 & 0.48 & 0.00 & 1.00 \\
\hline Education & 4173 & 1.68 & 0.64 & 0.00 & 3.00 \\
\hline Political interest & 4175 & 0.76 & 0.24 & 0.00 & 1.00 \\
\hline Social trust & 4180 & 0.67 & 0.23 & 0.00 & 1.00 \\
\hline \multicolumn{6}{|l|}{ WAVE 1 (Ban Fur Farming) } \\
\hline Political trust & 1397 & 0.47 & 0.21 & 0.00 & 0.93 \\
\hline Supported citizens' initiative & 1419 & 0.37 & 0.48 & 0.00 & 1.00 \\
\hline Process satisfaction & 1416 & 0.37 & 0.48 & 0.00 & 1.00 \\
\hline Age & 1418 & 38.49 & 12.93 & 17 & 80 \\
\hline Gender ( $1=$ male $)$ & 1401 & 0.63 & 0.48 & 0.00 & 1.00 \\
\hline Education & 1417 & 1.67 & 0.64 & 0.00 & 3.00 \\
\hline Political interest & 1414 & 0.75 & 0.24 & 0.00 & 1.00 \\
\hline Social trust & 1419 & 0.64 & 0.24 & 0.00 & 1.00 \\
\hline \multicolumn{6}{|l|}{ WAVE 2 (Copyright legislation) } \\
\hline Political trust & 1022 & 0.45 & 0.21 & 0.00 & 0.88 \\
\hline Supported citizens' initiative & 1022 & 0.57 & 0.50 & 0.00 & 1.00 \\
\hline Process satisfaction & 1022 & 0.17 & 0.37 & 0.00 & 1.00 \\
\hline Age & 1022 & 38.50 & 12.57 & 17 & 80 \\
\hline Gender ( $1=$ male $)$ & 1013 & 0.66 & 0.47 & 0.00 & 1.00 \\
\hline Education & 1020 & 1.70 & 0.64 & 0.00 & 3.00 \\
\hline Political interest & 1022 & 0.74 & 0.24 & 0.00 & 1.00 \\
\hline Social trust & 1022 & 0.67 & 0.23 & 0.00 & 1.00 \\
\hline \multicolumn{6}{|c|}{ WAVE 3 (Gender neutral marriage legislation) } \\
\hline Political trust & 930 & 0.49 & 0.20 & 0.00 & 0.98 \\
\hline Supported citizens' initiative & 930 & 0.70 & 0.46 & 0.00 & 1.00 \\
\hline Process satisfaction & 930 & 0.39 & 0.49 & 0.00 & 1.00 \\
\hline Age & 930 & 39.02 & 13.28 & 17 & 80 \\
\hline Gender ( $1=$ male $)$ & 923 & 0.62 & 0.49 & 0.00 & 1.00 \\
\hline Education & 929 & 1.68 & 0.64 & 0.00 & 3.00 \\
\hline Political interest & 930 & 0.76 & 0.23 & 0.00 & 1.00 \\
\hline Social trust & 930 & 0.69 & 0.23 & 0.00 & 1.00 \\
\hline \multicolumn{6}{|l|}{ WAVE 4 (Make Swedish voluntary) } \\
\hline Political trust & 809 & 0.48 & 0.20 & 0.00 & 0.90 \\
\hline Supported citizens' initiative & 809 & 0.33 & 0.47 & 0.00 & 1.00 \\
\hline Process satisfaction & 809 & 0.34 & 0.48 & 0.00 & 1.00 \\
\hline Age & 808 & 40.62 & 13.70 & 17 & 80 \\
\hline Gender ( 1 = male) & 799 & 0.65 & 0.48 & 0.00 & 1.00 \\
\hline Education & 807 & 1.69 & 0.65 & 0.00 & 3.00 \\
\hline Political interest & 809 & 0.77 & 0.23 & 0.00 & 1.00 \\
\hline Social trust & 809 & 0.68 & 0.23 & 0.00 & 1.00 \\
\hline Survey: Kansalaisaloite.fi & $n$ & mean & SD & Min & Max \\
\hline Perceived development in political trust & 475 & 0.33 & 0.23 & 0.00 & 1.00 \\
\hline Supported citizens' initiative & 477 & 0.54 & 0.30 & 0.00 & 1.00 \\
\hline Age & 436 & 41.91 & 15.85 & 18 & 86 \\
\hline Gender ( $1=$ male $)$ & 449 & 0.44 & 0.50 & 0.00 & 1.00 \\
\hline Education & 478 & 1.49 & 0.74 & 0.00 & 3.00 \\
\hline Political interest & 472 & 0.75 & 0.22 & 0.00 & 1.00 \\
\hline Social trust & 474 & 0.57 & 0.22 & 0.00 & 1.00 \\
\hline
\end{tabular}


Table A4. Factor analyses of political trust items.

\begin{tabular}{lcccccc}
\hline & \multicolumn{4}{c}{ Survey: Avoin Ministeriö } & & Survey: Kansalaistaloite.fi \\
\hline & Round 1 & Round 2 & Round 3 & Round 4 & Combined & Change pol. trust \\
\hline Trust parliament & 0.91 & 0.91 & 0.91 & 0.91 & 0.91 & 0.91 \\
Trust politicians & 0.92 & 0.92 & 0.92 & 0.91 & 0.92 & 0.96 \\
Trust political parties & 0.89 & 0.91 & 0.91 & 0.91 & 0.90 & 0.92 \\
Trust government & 0.88 & 0.88 & 0.87 & 0.87 & 0.88 & 0.91 \\
\hline Eigenvalue & 3.24 & 3.28 & 3.26 & 3.23 & 3.26 & 3.43 \\
Eigenvalue Factor 2 & 0.32 & 0.32 & 0.36 & 0.36 & 0.33 & 0.26 \\
Cronbach's alpha & 0.92 & 0.93 & 0.92 & 0.92 & 0.92 & 0.94 \\
Observations & 1393 & 1022 & 930 & 809 & 4154 & 475
\end{tabular}

Notes: Entries are unrotated factor loadings from principal-component factor analyses using the Principal Component Factoring (PCF) procedure in Stata. Substantially identical results were obtained using the Principal Factor method (FP), the Iterated Principal Factor method (IPF) and Maximum-Likelihood factor method (ml). Since a one-dimensional solution under all circumstances appear optimal, there is no need for rotation to interpret the results. 
Table A5. Regression analyses of individual trust items.

\begin{tabular}{|c|c|c|c|c|c|c|c|c|c|c|c|c|}
\hline \multirow[t]{2}{*}{ Avoin Ministeriö } & \multicolumn{3}{|c|}{ Trust parliament } & \multicolumn{3}{|c|}{ Trust politicians } & \multicolumn{3}{|c|}{ Trust political parties } & \multicolumn{3}{|c|}{ Trust government } \\
\hline & B & (SE) & $\mathbf{P}$ & B & (SE) & $\mathbf{P}$ & B & (SE) & $\mathbf{P}$ & B & (SE) & $\mathbf{P}$ \\
\hline Supported citizens' initiative & -0.013 & $(0.005)$ & 0.011 & -0.013 & $(0.005)$ & 0.008 & -0.011 & $(0.005)$ & 0.030 & -0.011 & $(0.005)$ & 0.043 \\
\hline Age & 0.002 & $(0.000)$ & 0.000 & 0.001 & $(0.000)$ & 0.088 & 0.001 & $(0.000)$ & 0.027 & 0.002 & $(0.000)$ & 0.000 \\
\hline Gender & -0.007 & $(0.011)$ & 0.492 & -0.014 & $(0.010)$ & 0.158 & -0.046 & $(0.011)$ & 0.000 & -0.038 & $(0.012)$ & 0.002 \\
\hline Education & 0.044 & $(0.008)$ & 0.000 & 0.034 & $(0.009)$ & 0.000 & 0.027 & $(0.008)$ & 0.000 & 0.046 & (0.009) & 0.000 \\
\hline Political interest & 0.065 & $(0.016)$ & 0.000 & 0.090 & $(0.015)$ & 0.000 & 0.101 & $(0.016)$ & 0.000 & -0.020 & $(0.017)$ & 0.226 \\
\hline Social trust & 0.165 & $(0.017)$ & 0.000 & 0.154 & $(0.015)$ & 0.000 & 0.144 & $(0.016)$ & 0.000 & 0.167 & $(0.017)$ & 0.000 \\
\hline \multicolumn{13}{|l|}{ Round (Ref: Ban Fur Farming) } \\
\hline Copyright legislation & -0.042 & $(0.006)$ & 0.000 & -0.018 & $(0.005)$ & 0.001 & -0.015 & $(0.006)$ & 0.007 & -0.028 & $(0.006)$ & 0.000 \\
\hline Gender neutral marriage legislation & -0.001 & $(0.006)$ & 0.820 & 0.013 & $(0.006)$ & 0.018 & 0.014 & $(0.006)$ & 0.014 & 0.005 & $(0.006)$ & 0.422 \\
\hline Make Swedish voluntary & -0.025 & $(0.006)$ & 0.000 & 0.000 & $(0.006)$ & 0.943 & 0.002 & $(0.006)$ & 0.775 & -0.016 & $(0.007)$ & 0.014 \\
\hline Constant & 0.224 & $(0.025)$ & 0.000 & 0.174 & $(0.023)$ & 0.000 & 0.176 & $(0.024)$ & 0.000 & 0.239 & $(0.026)$ & 0.000 \\
\hline \multicolumn{13}{|l|}{ Random effects } \\
\hline var(round) & 0.001 & $(0.000)$ & & 0.000 & $(0.000)$ & & 0.001 & $(0.000)$ & & 0.001 & $(0.000)$ & \\
\hline $\operatorname{var}($ cons) & 0.038 & $(0.003)$ & & 0.034 & $(0.002)$ & & 0.041 & $(0.003)$ & & 0.052 & $(0.003)$ & \\
\hline $\operatorname{cov}($ round, cons) & -0.001 & $(0.001)$ & & -0.001 & $(0.001)$ & & -0.003 & $(0.001)$ & & -0.003 & $(0.001)$ & \\
\hline var(Residual) & 0.015 & $(0.001)$ & & 0.014 & $(0.001)$ & & 0.014 & $(0.001)$ & & 0.014 & $(0.001)$ & \\
\hline Snijders/Boskers R2 level 1 & & 0.14 & & & 0.13 & & & 0.11 & & & 0.11 & \\
\hline Snijders/Boskers R2 Level 2 & & 0.17 & & & 0.16 & & & 0.13 & & & 0.13 & \\
\hline ICC & & 0.72 & & & 0.71 & & & 0.75 & & & 0.76 & \\
\hline $\mathrm{N}$ & & $399 / 4121$ & & & $399 / 4120$ & & & $399 / 4114$ & & & $99 / 4111$ & \\
\hline \multirow[t]{2}{*}{ Kansalaisaloite.fi } & \multicolumn{3}{|c|}{ Trust parliament } & \multicolumn{3}{|c|}{ Trust politicians } & \multicolumn{3}{|c|}{ Trust political parties } & \multicolumn{3}{|c|}{ Trust government } \\
\hline & B & (SE) & $\mathbf{P}$ & B & (SE) & $\mathbf{P}$ & B & (SE) & $\mathbf{P}$ & B & (SE) & $\mathbf{P}$ \\
\hline Supported citizens' initiative & -0.040 & $(0.011)$ & 0.000 & -0.033 & $(0.011)$ & 0.002 & -0.036 & $(0.010)$ & 0.001 & -0.035 & $(0.010)$ & 0.001 \\
\hline Age & -0.003 & $(0.001)$ & 0.000 & -0.003 & $(0.001)$ & 0.000 & -0.004 & $(0.001)$ & 0.000 & -0.003 & $(0.001)$ & 0.000 \\
\hline Gender & -0.027 & $(0.026)$ & 0.292 & -0.005 & $(0.024)$ & 0.828 & -0.040 & $(0.023)$ & 0.084 & 0.010 & $(0.024)$ & 0.675 \\
\hline Education & 0.047 & $(0.018)$ & 0.010 & 0.040 & $(0.017)$ & 0.017 & 0.028 & $(0.016)$ & 0.090 & 0.041 & $(0.017)$ & 0.015 \\
\hline Political interest & 0.010 & $(0.057)$ & 0.859 & 0.017 & $(0.055)$ & 0.762 & 0.080 & $(0.052)$ & 0.125 & -0.078 & $(0.055)$ & 0.153 \\
\hline Social trust & 0.320 & $(0.060)$ & 0.000 & 0.317 & $(0.057)$ & 0.000 & 0.319 & $(0.057)$ & 0.000 & 0.218 & $(0.058)$ & 0.000 \\
\hline Constant & 0.357 & $(0.072)$ & 0.000 & 0.283 & $(0.070)$ & 0.000 & 0.315 & $(0.065)$ & 0.000 & 0.407 & $(0.069)$ & 0.000 \\
\hline $\mathbf{N}$ & & 0.17 & & & 0.16 & & & 0.20 & & & 0.23 & \\
\hline R2 & & 397 & & & 395 & & & 397 & & & 397 & \\
\hline
\end{tabular}

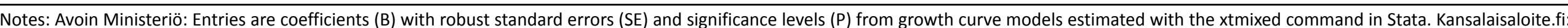
Entries are coefficients (B) from linear regression analyses with robust standard errors (SE) and significance levels (P). 